No 4078

Studia nad Autorytaryzmem i Totalitaryzmem 43, nr 4 Wrocław 2021

https://doi.org/10.19195/2300-7249.43.4.16

\author{
DOBROMIŁA NOWICKA \\ ORCID: 0000-0002-1480-7281 \\ Uniwersytet Wrocławski \\ dobromila.nowicka@uwr.edu.pl
}

\title{
Palenie ksiąg w starożytnym Rzymie jako przejaw autorytarnego ograniczania republikańskiej wolności słowa
}

Slowa kluczowe: palenie ksiąg, wolność słowa, pryncypat, crimen maiestatis.

\author{
BOOK BURNING IN ANCIENT ROME AS A MANIFESTATION \\ OF AUTHORITARIAN LIMITATION OF THE REPUBLICAN FREEDOM OF SPEECH
}

\begin{abstract}
Transition from republic to principate brought a meaningful alteration in the area of conceiving freedom of speech. Republican standards in this matter were not apt for the new regime as it was too fragile to withstand the republican dissidence. New restrictions and ad hoc measures needed to be applied. Among them burning of books was of particular importance.

The article deals with incidents of book burning in the times of Augustus (cases of Titus Labienus and Cassius Severus) and Tiberius (those of Mamercus Scaurus and Cremutius Cordus), which, although not numerous, were of high significance for freedom of speech within the new regime. On the basis of analysis of selected ancient sources and scientific literature on the matter, an answer to the question about their political meaning is sought. Accordingly, the socio-political background of change in the area of freedom of speech in the context of passing from a republic to the authoritarian regime of a principate needs to be taken into account. Unfortunately, historical sources regarding the matter are deeply unequivocal and scientific interpretations seem strongly conditioned by tendencies to discern crimen maiestatis in every case of book burning from the times of early empire, even if it is not plainly attested by ancient authors. It appears that the subsequent popularity of maiestas charges could have influenced the erroneous interpretation of previous incidents, which appear to have been - at least formally — distant from the law of injured majesty, being ad hoc measures at least in the times of the reign of Augustus.

However, the essential point of analysis concerns the grounds of the incidents of burning books that took place under August and Tiberius, showing a step-by-step process of supressing the repub-
\end{abstract}


lican freedom of speech. Although rare, book burnings reflect a common tendency in new authoritarian rulers' politics, which at first tend to deal with opponents unpopular among the aristocracy, only to move on to managing adversaries originating from the Roman élite. Nevertheless, the undertaken measures were not suitable for annihilating the books in question, contributing to their growth in popularity. The answer to the core question about the aims of book burnings under Augustus and Tiberius seems to boil down to mere propaganda, showing that dissident books would not be tolerated, no matter the social status of their authors.

Keywords: book burning, freedom of speech, principate, crimen maiestatis.

Problematyka związana z paleniem ksiąg w starożytnym Rzymie cieszy się niesłabnącym zainteresowaniem nie tylko wśród przedstawicieli nauki prawa rzymskiego i historyków zainteresowanych antykiem, zajmując od lat badaczy starożytności oraz tych, którzy do niej sięgają, analizując późniejsze — w tym współczesne - zjawiska społeczne czy polityczne. Wydaje się, że z jednej strony jest to pokłosie wieloaspektowości tej tematyki, w której mieszczą się zagadnienia związane z wolnością słowa, sposobem sprawowania władzy, konfliktami społecznymi, polityką, literaturą, religią czy magią. Z drugiej natomiast zwraca uwagę ponadczasowość zjawiska, które od starożytności po czasy najnowsze bywa obecne $\mathrm{w}$ różnych reżimach politycznych, stanowiąc przejaw autorytaryzmu w sprawowaniu władzy.

Niniejsze opracowanie poświęcone jest jedynie niewielkiej części tej złożonej kwestii i ogranicza się do krótkiej analizy najbardziej znanych przypadków palenia ksiąg, mających miejsce za rządów Augusta i Tyberiusza. Jakkolwiek bowiem już w dobie republiki doszło do wprowadzenia zakazu posiadania określonych ksiąg, a nawet ich palenia ${ }^{1}$, było to związane $\mathrm{z}$ ich profetycznym charakterem i ściśle nawiązywało do uzasadnienia religijnego i chęci „oczyszczenia" państwa rzymskiego z praktyk uznanych za szkodliwe ${ }^{2}$. Mimo że obawy te $\mathrm{z}$ pewnością były powiązane $\mathrm{z}$ brakiem kontroli państwa nad działalnością tego rodzaju i ryzykiem pojawienia się w jej ramach tendencji zakłócających ówczesne status quo, z uwagi na swój nie tylko polityczny charakter zostaną one tu pominięte w związku z tym, że artykuł ten koncentruje się na nieznanej republice

${ }^{1}$ C.A. Forbes, Books for the Burning, ,Transactions and Proceedings of the American Philological Association" 1936, nr 67, s. 118; J.A. Howley, Book-Burning and the Uses of Writing in Ancient Rome: Destructive Practice between Literature and Document, „The Journal of Roman Studies" 2017, nr 107, s. 215-217; D. Rohmann, Book Burning as Conflict Management in the Roman Empire (213 BCE-200 CE), „Ancient Society” 2013, nr 43, s. 119-122. Podkreślenia wymaga jednak, że tylko jeden przypadek palenia ksiąg nie budzi wątpliwości.

2 Szerzej zob. J. Herrin, Book Burning as Purification, [w:] Transformations of Late Antiquity. Essays for Peter Brown, red. P. Rousseau, M. Papoutsakis, Farnham 2009, s. 205-222; D.C. Sarefield, Bookburning in the Christian Roman Empire. Transforming a Pagan Rite of Purification, [w:] Violence in Late Antiquity, red. H.A. Drake, Aldershot 2006, s. 287-296. 
praktyce niszczenia ksiąg mogących zagrozić nowemu porządkowi z powodów stricte politycznych.

Republikańska wolność słowa ${ }^{3}$ stanowiła w Rzymie podstawę debaty publicznej zarówno $\mathrm{w}$ formie zinstytucjonalizowanej, jak i tej nieformalnej. Co warte podkreślenia, nie opierała się ona na żadnym akcie prawnym, który gwarantowałby każdemu obywatelowi prawo do swobodnego wyrażania poglądów — była inherentnie związana $\mathrm{z}$ samą koncepcją res publica ${ }^{4}$. $\mathrm{Z}$ tego też względu można mówić o szerokim zakresie libertas ${ }^{5} \mathrm{w}$ odniesieniu do wypowiedzi także nieprzychylnych, które - pod warunkiem że nie miały charakteru naruszającego cześć człowieka wolnego - nie były uznawane za przejawy szkodliwej magii i nie wpisywały się w organizowanie seditio, nie prowadziły bezpośrednio do odpowiedzialności ich autorów. Dodatkowo istniały liczne okoliczności, które niejako legitymizowały wypowiadanie słów kwalifikujących się już w oderwaniu od nich jako naruszające czyjeś dobre imię — tak było w przypadku twierdzeń czy określeń używanych podczas określonych uroczystości ${ }^{6}$, zinstytucjonalizowanej debaty publicznej, jak ta $\mathrm{w}$ senacie ${ }^{7}$, czy mów sądowych, co dobitnie poświadczają inwektywy obecne w mowach Cycerona ${ }^{8}$. Jakkolwiek nie eliminowały one

3 Zob. zwł. L. Robinson, Freedom of Speech in the Roman Republic, Baltimore 1940, passim; J.M. Díaz de Valdéz, Freedom of Speech in Rome [Libertad de expresión en Roma], „Revista de Estudios Histórico-Jurídicos" 2009, nr 31, s. 129-133; R.A. Bauman, Human Rights in Ancient Rome, London 2000, s. 102-103. Na temat jednak nie do końca określonego zakresu maiestas w dobie późnej republiki zob. zwł. R. Seager, Maiestas in the Late Republic: Some Observations, [w:] Critical Studies in Ancient Law, Comparative Law and Legal History, red. J.W. Cairns, O.F. Robinson, Oxford 2001, s. 143-153.

4 Zob. J.M. Díaz de Valdéz, op. cit., s. 127-129, 136-137. Zob. też D.J. Kapust, The Case of Cremutius Cordus: Tacitus on Censorship and Writing under Despotic Rulers, [w:] Censorship Moments: Reading Texts in the History of Censorship and Freedom of Expression, red. G. Kemp, London-New Delhi-New York-Sydney 2015, s. 18-19. O wolności słowa w powiązaniu z humanitas zob. R.A. Bauman, op. cit., s. 101.

5 Zob. zwł. Ch. Wirszubski, Libertas as a Political Idea at Rome during the Late Republic and Early Principate, Cambridge 1950, s. 97-123; K.A. Raaflaub, Aristocracy and Freedom of Speech in the Greco-Roman World, [w:] Free Speech in Classical Antiquity, red. I. Sluiter, R.M. Rosen, Leiden-Boston 2004, s. 54-57; por. S.G. Chrissanthos, Freedom of Speech and the Roman Republican Army, [w:] Free Speech..., s. 342-348; Ch. Chinn, "Libertas Reverentiam Remisit": Politics and Metaphor in Statius “Silvae” 1.6, „The American Journal of Philology” 129, 2008, nr 1, s. 101-124; S.M. Braund, Libertas or licentia? Freedom and Criticism in Roman Satire, [w:] Free Speech..., s. $409-428$.

${ }^{6}$ Zob. np. A.D. Manfredini, La diffamazione verbale nel diritto romano, Milano 1978, s. 65. Na temat libertas w rzymskich realiach wojskowych zob. zwł. S.G. Chrissanthos, op. cit., s. 348-356.

7 Ch.G. Starr Jr., The Perfect Democracy of the Roman Empire, „The American Historical Review" 58, 1952, nr 1, s. 1-16. Zob. też D. Nowicka, Rzymski senat a wolność słowa, [w:] Zgromadzenia stanowe i organy przedstawicielskie $w$ dziejach. Ksiegga jubileuszowa dedykowana Profesorowi Marianowi Józefowi Ptakowi, red. J. Koredczuk, P. Wiązek, Wrocław 2020, s. 315-322.

8 Zob. zwł. A. Corbeill, Ciceronian Invective, [w:] Brill's Companion to Cicero: Oratory and Rhetoric, red. J.M. May, Leiden 2002, s. 197-217; C. Steel, Name and Shame? Invective against 
możliwości złożenia formalnej skargi, w praktyce były uważane za dopuszczalne i niestanowiące obrazy. Pewna licentia, choć już nie w tak szerokim zakresie, charakteryzowała także podejście Rzymian do utworów poetyckich. Podkreślenia jednak wymaga, że obowiązujące w republice ograniczenia wolności słowa - poza jawnym nawoływaniem do buntu czy recytowaniem szkodliwych zaklęć - były związane jedynie z ochroną czci osób prywatnych, które w pełni autonomicznie podejmowały decyzje o dochodzeniu odszkodowania na drodze powództwa prywatnego. Oceny dotyczące zachowania osób sprawujących funkcje publiczne nie pociągały za sobą odpowiedzialności ich autora, jeśli dodatkowo nie wyczerpywały znamion wskazanych czynów ${ }^{9}$. Tym samym zakres dopuszczalnej wolności słowa, w tym krytyki, w dobie republiki był bardzo szeroki i obowiązywał w sposób dorozumiany.

Przejście do innej formy państwa $\mathrm{z}$ nadejściem pryncypatu nie zmieniło tej sytuacji od razu, jako że August w pierwszych latach swych rządów starał się utrzymywać pozór dalszego funkcjonowania wolności słowa, choć nie $\mathrm{w}$ dotychczas znanym zakresie ${ }^{10}$. Wykazywał się dużą tolerancją, gdy chodzi o pisma go zniesławiające, choć podejmował też kroki mające na celu ograniczenie zasięgu rozpowszechniania nieprzychylnych mu i nowemu porządkowi wypowiedzi, także padających podczas debat w senacie ${ }^{11}$. Nie wydaje się jednak, by pozostawał w nieświadomości co do możliwych następstw politycznych formułowanych ataków, raczej nie chciał podjąć szeroko zakrojonych, stanowczych działań w celu ich tłumienia, jako że stałoby to w jawnej sprzeczności $\mathrm{z}$ utrzymywaniem fasady kontynuacji w tym względzie zasad zbliżonych do republikańskich ${ }^{12}$.

Clodius and Others in the Post-Exile Speeches, [w:] Cicero on the Attack: Invective and Subversion in the Orations and Beyond, red. J. Booth, Swansea 2007, s. 105-128.

${ }^{9}$ Warto w tym kontekście zwrócić uwagę na słynny przypadek Naeviusa. Szerzej zob. zwł. H.B. Mattingly, Naevius and the Metelli, „Historia: Zeitschrift für Alte Geschichte” 9, 1960, nr 4, s. 414-439; B. Santalucia, La carcerazione di Naevio, [w:] idem, Altri studi di diritto penale romano, Milano 2009, s. 371-387 z powołaną tam literaturą. Zob. też R.A. Bauman, The Crimen Maiestatis in the Roman Republic and Augustan Principate, Johannesburg 1967, s. 246-247; R.E. Smith, The Law of Libel at Rome, „The Classical Quarterly” 1, $1951 \mathrm{nr} 3-4$, s. 170-171.

10 Zob. F.H. Cramer, Bookburning and Censorship in Ancient Rome: A Chapter from the History of Freedom of Speech, „Journal of the History of Ideas” 6, 1945, nr 2, s. 163-167. O watpliwościach co do zakresu dopuszczalnej wolności słowa, także w odniesieniu do późniejszych cesarzy, zob. E. Watts, Introduction: Freedom of Speech and Self-Censorship in the Roman Empire, „Revue Belge de Philologie et d'Histoire / Belgisch Tijdschrift voor Filologie en Geschiedenis” 2014, nr 92, s. $160-162$.

11 Zob. np. R.A. Bauman, The Crimen Maiestatis..., s. 251-252; T. Polański, The Destructive Force of Roman Censorship. A Retrospective View across the Limes, [w:] Essays in Honour of S. Stabryła, red. S. Styka, Kraków 2007, s. 265.

12 Zob. F.H. Cramer, op. cit., s. 157, 163-164; J.M. Díaz de Valdéz, op. cit., s. 134-135; por. I.J. Colunga, Untangling a Historian's Misinterpretation of Ancient Rome's Treason Laws, ,Journal Jurisprudence" 2011, nr 9, s. 17-18. 
Przełomowe w tym zakresie były ostatnie lata panowania Augusta, gdy doszło do pierwszego aktu spalenia ksiąg z powodów innych niż związane ze sferą religijno-magiczną ${ }^{13}$, przy czym zmiany polityki Augusta upatruje się niekiedy w zwiększającym się znaczeniu opinii jego najbliższego otoczenia, w tym Tyberiusza.

Jakkolwiek istnieją wątpliwości co do tego, w stosunku do którego z autorów jako pierwszego zastosowano sankcję $\mathrm{w}$ postaci spalenia jego dorobku literackiego ${ }^{14}$, wydaje się, że był nim, znany z zuchwałej krytyki inlustres, zwolennik ustroju republikańskiego, Titus Labienus ${ }^{15}$. Nie jest przy tym pewne, czy to właśnie $z$ uwagi na zaciekłe ataki na najznamienitszych przedstawicieli ludu rzymskiego ${ }^{16}$, czy też z powodu zarzutów lub ocen formułowanych pod adresem princepsa i nowego reżimu, doszło do zarządzenia spalenia jego ksiąg. Podobny los spotkał następnie księgi prorepublikańskiego Cassiusa Severusa ${ }^{17}$, także znanego z ostrej krytyki społecznej elity Rzymu, choć również w tym przypadku uzasadnienie interwencji mogło mieć związek z ochroną wizerunku władcy. W tym wypadku oprócz spalenia ksiąg ich autor został wygnany, lecz z powodu kontynuowania twórczości na wygnaniu, już za Tyberiusza, zasądzono wobec niego aquae et igni interdictio.

Podkreślenia wymaga, że źródła w odniesieniu do obu sytuacji są wyjątkowo niejednoznaczne, nie tylko jeśli chodzi o daty obu wydarzeń ${ }^{18}$, ale też ich rzeczywiste uzasadnienie i podstawę prawną ${ }^{19}$. Najczęściej uznaje się, że miały one

13 Suetonius, Augustus, 31.1. Zob. też F.H. Cramer, op. cit., s. 167-168; J.A. Howley, op. cit., s. 219; D. Rohmann, op. cit., s. 134-135.

14 Związane jest to z odmiennymi stanowiskami Seneki i Tacyta. Zob. np. V. Rudich, Navigating the Uncertain: Literature and Censorship in the Early Roman Empire, „Arion” 2006, nr 14, s. 14.

15 Zob. Seneca Rhetor, Controversiae 10, praef. 4; Tacitus, Annales, 4.34; D. Henning, T. Labienus und der erst Majestätprozeß de famosis libellis, „Chiron” 1973, nr 3, s. 245-254; D. Rohmann, op. cit., s. 130-131; F.H. Cramer, op. cit., s. 172-175.

16 Tak D. Rohmann w odniesieniu do senatorów; zob. idem, op. cit., s. 130.

17 Zob. Tacitus, Annales, 1.72; Seneca Rhetor, Controversiae 10, praef. 5-8; A. D’Hautcourt, L'exile de Cassius Severus: hypothèse nouvelle, „Latomus” 54, 1995, nr 2, s. 315-318; D. Rohmann, op. cit., s. 131-132; F.H. Cramer, op. cit., s. 175-177; R.A. Bauman, The Crimen Maiestatis..., s. $257-260$.

18 Zob. J.A. Howley, op. cit., s. 217-218.

19 O kontrowersjach zob. np. V. Rudich, op. cit., s. 9-10; J.A. Howley, op. cit., s. 217; R.A. Bauman, The Crimen Maiestatis..., s. 246-265; M. Balzarini, ,De iniuria extra ordinem statui”. Contributo allo studio del diritto penale romano dell'età classica, Padova 1983, s. 104-121; idem, Ancora sul Lex Cornelia de iniuriis e sulla repressione di talune modalità di diffamazione, [w:] Estudios en Homenaje al Profesor Juan Iglesias, red. J.R. Esteve, t. 2, Madrid 1988, s. 590-594; G. Mucciacia, In tema di repressione delle opere infamanti, [w:] Studi in onore di Arnaldo Biscardi, t. 5, Milano 1984, s. 61-78; D. Nowicka, Some Remarks on Criminalization of Written Defamation in Roman Classical Law, [w:] "They Called Me to Destroy the Wicked and the Evil": Selected Essays on Crime and Punishment in Antiquity, red. S. Nowicki, Münster 2016, s. 130-139. Wątpliwości w największej mierze dotyczą następujących źródeł i relacji między nimi: Suetonius, Augustus, 55; Tacitus, 
miejsce w 12 lub 13 roku n.e., choć niektórzy badacze ${ }^{20}$ umieszczają datę pierwszego spalenia ksiąg nawet między 6 a 8 rokiem n.e. Druga kontrowersja dotyczy znaczenia wzmianek na temat zaciekłych ataków na inlustres $\mathrm{w}$ odniesieniu do obu przypadków, odpowiednio u Seneki Starszego (Labienus) oraz Tacyta (Cassius Severus). Obaj autorzy spalonych ksiąg byli też znani z licznych i ostrych wypowiedzi przeciw nowemu reżimowi, dodatkowo otwarcie prezentowali nieprzychylne Augustowi postawy prorepublikańskie.

Zwolennicy tezy, że incydenty palenia ksiąg miały związek z działalnością tych autorów skierowaną przeciw możnym ${ }^{21}$, postulują uznanie, że podstawą spalenia ksiąg były procesy na gruncie nowego prawa, mającego stanowić wypadkową ustawodawstwa decemwiralnego, dotyczącego mala carmina oraz poświęconego crimen maiestatis, toczącego się przed senatem ${ }^{22}$. Jako że nie istnieją jakiekolwiek wzmianki źródłowe mogące poświadczyć takie rozwiązanie legislacyjne, teza ta nie może w najmniejszym stopniu zostać uznana za uzasadnioną. Innym rozwiązaniem jest przyjęcie, że podstawą było wyłącznie naruszenie maiestas, co skutkuje albo uznaniem za nie zniesławienia przedstawicieli elit rzymskich $^{23}$, albo też sugeruje, że palenie ksiąg miało bezpośredni związek z antycesarskimi wypowiedziami obu autorów ${ }^{24}$. Jakkolwiek ta druga interpretacja jest bardziej przekonująca $\mathrm{z}$ uwagi na zgodność z założeniami lex de maiestate, która mogła być zastosowana także do działań słownych/pisemnych, co stanowiło novum w stosunku do dotychczasowej praktyki, jednak mieściło się w ochronie maiestas na gruncie bardzo pojemnej ustawy regulującej jej naruszenia, nie do końca odpowiada to znanej już wcześniej polityce Augusta w tym zakresie, a nawet podejściu Tyberiusza z pierwszych lat jego rządów. Wydaje się, że rozważyć należy jeszcze jedno rozwiązanie - uznanie, że uchwały senatu zarządzające palenie ksiąg miały charakter działań ad hoc, oczywiście inspirowanych przez Augusta $^{25}$. Nie tylko bowiem eliminowałoby to problemy będące skutkiem dążenia do wpisania tych działań w ramy znanych rozwiązań, jak i tworzenia sztucznych, nieznajdujących potwierdzenia w źródłach koncepcji opartych na fuzji ustaw,

Annales, 1.72 oraz dwóch przekazów Cassiusa Diona, Historia Romana, 55,27,1-3 oraz 56,27,1. Zob. też D. Nowicka, Zniesławienie w prawie rzymskim, Wrocław 2013, s. 86-94.

20 Zob. F.H. Cramer, op. cit., s. 173.

21 Zob. ibidem, s. 169; także za nim na przykład T. Polański, op. cit., s. 266.

22 Zob. V. Rudich, op. cit., s. 11-12; M.R. McHugh, Historiography and Freedom of Speech: The Case of Cremudius Cordus, [w:] Free Speech..., s. 393. Por. D. Rohmann, op. cit., s. 131.

${ }^{23} \mathrm{Na}$ temat zniesławień senatorów jako podstawy senatus consultum w przypadku Labienusa zob. D. Rohmann, op. cit., s. 130. Podobnie w stosunku do Scaurusa - ibidem, s. 132. O interpretacji zniewag wobec klasy rządzącej jako naruszenia maiestas zob. np. A.Z. Bryen, Labeo's iniuria: Violence and Politics in the Age of Augustus, „Chiron” 2018, nr 48, s. 12-13.

${ }^{24}$ Tę ostatnią linię interpretacyjną przyjmuje na przykład V. Rudich, op. cit., s. 14-15. Zob. też D.J. Kapust, op. cit., s. 19.

25 Tak D. Nowicka, Some Remarks..., s. 138, 153. Zob. też M. Balzarini, De iniuria ..., s. 104 122 , zwł. s. $114,120-122$. 
lecz także wpisywałoby się w charakter poprzednich przedsięwzięć tego typu, nie łącząc palenia ksiąg z crimen maiestatis.

Niezależnie jednak od przyjętej interpretacji - występowania Augusta w imieniu własnym czy formalnie w obronie „elit” bądź też ad hoc w celu zachowania porządku publicznego - nie budzi raczej wątpliwości, co w rzeczywistości było celem wydanych senatus consulta. Spalenie ksiąg było jasnym sygnałem, że zuchwałe występowanie przeciw nowemu reżimowi, mimo że nie zawiera bezpośrednich nawoływań do podjęcia działań w celu jego obalenia, nie będzie tolerowane. Republikańska wolność słowa nie odpowiadała bowiem potrzebom princepsa i jego otoczenia, senat zaś nie miał już charakteru niezależnego, będąc podporządkowanym woli Augusta. Ten jednak nie odważył się na ograniczenie swobody dyskusji i krytyki w ramach jego posiedzeń, a - co szczególnie znamienne - przypadki palenia ksiąg przeciwników nowego ustroju nie tylko były ograniczone do osób pochodzących z ubogich rodzin, z pewnością nienależących do inlustres ${ }^{26}$, lecz także — jak można przypuszczać, nieprzypadkowo — znanych z zuchwałej krytyki elit, których reprezentacja zasiadała w senacie. Tym samym wydaje się, że senatus consulta, które przewidywały tak drastyczne konsekwencje jak oficjalne zniszczenie dorobków Titusa Labienusa i Cassiusa Severusa, mimo sprzeciwu niektórych senatorów, nie musiały budzić w tym gronie tak nieprzychylnych ocen, jakich można by się było spodziewać w odniesieniu do innych autorów.

W okresie tak nieodległym od ustroju republikańskiego, gdy nowy reżim nie był jeszcze ustabilizowany, a prorepublikańskie lub też antymonarchiczne emocje w oczywisty sposób pozostawały świeże, wprowadzanie cenzury i ograniczanie wolności wypowiedzi z przyczyn politycznych musiało następować sukcesywnie, nie pozostawiając jednak złudzeń co do kierunku działań władzy i możliwości zastosowania represji nie tylko wobec mniej znaczących członków społeczeństwa rzymskiego. Podkreślenia wymaga, że incydentom palenia ksiąg w tym okresie towarzyszyły inne przejawy autorytarnego ograniczania wolności słowa, jak na przykład cenzura populi acta diurna, stanowiących pierwszą rzymską „,gazetę"27. Nie można w tym kontekście nie wspomnieć także o zmianie w zakresie ścigania anonimowych bądź pisanych pod pseudonimem paszkwili, w których wypadku osoby pokrzywdzone uzyskały mocniejszą ochronę z powodu wprowadzenia mieszanej, publiczno-prywatnej procedury w sprawach tego rodzaju ${ }^{28}$.

${ }^{26}$ Zob. T. Polański, op. cit., s. 269, który sugeruje, że to ich niskie pochodzenie sprawiło, że procesy były traktowane przez władzę jako „testowe”, co torowało drogę procesom osób z kręgów arystokratycznych, którzy stanowili dla cesarza prawdziwe zagrożenie.

27 Zob. F.H. Cramer, op. cit., s. 161-162; Na temat acta senatus zob. też A. Vannucci, I giornali presso gli antichi Romani, „Archivio Storico Italiano. Nuova Serie” 9, 1859, nr 1, s. 128-134; M. Coudry, Sénatus-consultes et acta senatus: rédaction, conservation et archivage des documents émanant du sénat, de l'époque de César à celle des Sévères, [w:] La mémoire perdue. À la recherche des archives oubliées, publiques et privées, de la Rome antique, red. S. Demougin, Paris 1994, s. 1-29.

${ }^{28}$ Zob. np. F.H. Cramer, op. cit., s. 168-169. Na temat anonimowych oraz pisanych pod pseudonimem pism zniesławiających i interwencji senackiej w tym zakresie za panowania Augusta zob. D. Nowicka, Zniesławienie..., s. 153-163 z podaną tam literaturą. 
Przejście władzy w ręce Tyberiusza, mimo znanych już wcześniej jego zapatrywań na kwestię zbyt łagodnego podejścia Augusta do atakujących go krytyków, nie przyniosło jednak nagłego wzrostu liczby incydentów palenia ksiąg, podobnie jak nie poskutkowało od razu skazaniami za crimen maiestatis w przypadku zniesławień cesarza czy jego matki ${ }^{29}$. Oczywiście czym innym były sytuacje, które mimo że odnosiły się jedynie do niefortunnej wypowiedzi, mogły być interpretowane jako stanowiące naruszenie maiestas rodziny cesarskiej. Co jednak znamienne, w wypadku słynnego procesu i skazania na śmierć Clutoriusa Priscusa $^{30}$ za przedwczesne stworzenie elegii pośmiertnej dla poważnie chorego Drususa, który jednak powrócił do zdrowia, co zostało uznane przez senat za wypełniające znamiona crimen maiestatis, nie zarządzono spalenia dzieła. Od początku lat dwudziestych coraz więcej skazań z tego tytułu tyczyło się jednak obraźliwych wypowiedzi na temat cesarza ${ }^{31}$.

Pierwszy przypadek spalenia ksiąg za Tyberiusza dotyczył Mamercusa Aemiliusa Scaurusa ${ }^{32}$, przy czym nie chodziło o wszystkie jego dzieła, a jedynie siedem spisanych mów. Dodatkowo prawdopodobnie była to jedyna sankcja, jaką wówczas poniósł Scaurus. Wydaje się, że tak łagodne potraktowanie tego zwolennika republiki i jego dzieł miało związek z pochodzeniem autora ze znamienitego rodu oraz jego ustosunkowaniem wśród inlustres mimo nieprzynoszącego mu chwały trybu życia. Podkreślenia wymaga, że nie wiadomo, czy wskutek jego późniejszego procesu, w którym jednym z zarzutów miała być „zdrada literacka” w związku z krótkim fragmentem jego tragedii (Atreus), doszło do spalenia jego pozostałych dzieł, ale jest to wysoce wątpliwe.

To jednak nie Scaurusa, a Cremutiusa Cordusa ${ }^{33}$ należy uznać za najbardziej znanego autora z czasów Tyberiusza, którego księgi zostały spalone. Wyjątkowość sytuacji tego pierwszego dotyczyła bowiem nie tylko jego pozycji społecznej, ale też - jak się wydaje w konsekwencji - selektywnego wyboru utworów, które miały zostać spalone. W przypadku Cordusa, który podobnie jak Scaurus piastował godność senatorską, podstawą spalenia ksiąg były bowiem fragmenty

29 Tacitus, Annales, 2.50 oraz 1.74.3-6; M.R. McHugh, op. cit., s. 399; I.J. Colunga, op. cit., s. 12, 18-21; F.H. Cramer, op. cit., s. 178-181; R.A. Bauman, Human Rights..., s. 102.

30 Por. ciekawą interpretację sytuacji przedstawioną przez V. Rudicha, op. cit., s. 22. Zob. też I.J. Colunga, op. cit., s. 21-22; F.H. Cramer, op. cit., s. 186-188.

31 Zob. np. T. Polański, op. cit., s. 269-270.

32 Zob. Seneca Rhetor, Controversiae 10, praef. 2-3; Suetonius, Tiberius, 61.3; Tacitus, Annales, VI, 9-30; D. Rohmann, op. cit., s. 132; F.H. Cramer, op. cit., s. 189-191.

33 Zob. Tacitus, Annales, 4.34-35; Suetonius, Tiberius, 61.3; Seneca, Ad Marciam, 1.2-4, 22.4-7, 26,1,3. Zob. np. M.R. McHugh, op. cit., s. 393-394 oraz 399-403; H. Tränkle, Zu Cremutius Cordus fr. 4 Peter, „Museum Helveticum” 37, 1980, nr 4, s. 231-241; D.J. Kapust, op. cit., s. 17-24; R.S. Rogers, The Case of Cremutius Cordus, „Transactions and Proceedings of the American Philological Association" 1965, nr 96, s. 351-359; J. Wisse, Remembering Cremutius Cordus: Tacitus on History, Tyranny and Memory, „Histos” 2013, nr 7, s. 299-361; D. Rohmann, op. cit., s. 127-129; F.H. Cramer, op. cit., s. 191-196; R.A. Bauman, Human Rights..., s. 104-105. 
jego dzieła o charakterze historycznym, jakkolwiek tendencje prorepublikańskie były w nim wyraźne. Nie dopuścił się on jednak ataków na cesarza, choć utrzymuje się, że nadmiernie chwalił Cassiusa i Brutusa, a także w niewystarczający sposób okazał szacunek Augustowi ${ }^{34}$. Był to więc pierwszy przypadek, w którym kopie dzieła o zupełnie innej naturze - Annales - miały zostać odszukane przez urzędników i spalone. Nie jest jasne, czy dotyczyło to jedynie tego dzieła, czy też całego dorobku Cordusa, choć wydaje się prawdopodobne, że tylko wspomnianych Annales. Co warte podkreślenia, fragmenty tego dzieła były znane Augustowi - podobnie jak Atreusa autorstwa Scaurusa — i nie wzbudziły jego zastrzeżeń. $Z$ jednej strony wzmacnia to wiarygodność znanego już w starożytności rzeczywistego podłoża procesów, ściśle powiązanego z prywatną wrogością inicjatorów postępowań w stosunku do wskazanych autorów, z drugiej — obrazuje zmianę, jaka w zakresie interpretacji dopuszczalności krytycznych wypowiedzi wobec władcy dokonała się w ciągu panowania dwóch pierwszych cesarzy.

Wydaje się jednak, że obie te kwestie są z sobą ściśle powiązane. Nie idealizując czasów Augusta, które zapoczątkowały tłumienie republikańskiej wolności słowa w starożytnym Rzymie ${ }^{35}$, należy uznać, że dopiero rządy Tyberiusza przyniosły jej daleko idące ograniczenia ${ }^{36}$. Wzrastające poczucie zagrożenia cesarza ${ }^{37}$ sprzyjało interpretacjom dotychczas dopuszczalnych pism w sposób rzekomo godzący $\mathrm{w}$ jego maiestas, stając się orężem $\mathrm{w}$ walce $\mathrm{z}$ wrogami politycznymi oraz sposobem na zemstę. Podkreślenia wymaga, że już przypadek spalenia wybranych pism Scaurusa, mimo wyjątkowo łagodnej sankcji, był ostrzeżeniem dla krytyków władzy, dobitnie ukazującym, że nawet członkowie stanu senatorskiego nie mogą czuć się bezpiecznie ${ }^{38}$. Na tym etapie nie zdecydowano się jednak jeszcze na podjęcie dalej idących kroków, lecz zarówno ten, jak i inne przejawy wciąż narastającego autorytaryzmu władcy, w tym coraz liczniejsze procesy o crimen maiestatis z coraz błahszych powodów, wyraźnie świadczyły o kierunku rozwoju polityki omawianego cesarza, zmierzającej nieuchronnie do stłumienia pozostałości republikańskiej wolności słowa.

34 Zob. Tacitus, Annales, 4.34; T. Polański, op. cit., s. 271; M.R. McHugh, op. cit., s. 400-401; D.J. Kapust, op. cit., s. 17-18. Podkreślenia wymaga jednak, że był to jeden z wachlarza zarzutów, które zostały mu postawione. D. Rohmann, op. cit., s. 127, utrzymuje, że pozostałe miały dla zasądzenia większe znaczenie niż tu analizowany. Por. też interesującą analizę w tym zakresie przeprowadzoną przez R.S. Rogersa, op. cit., s. 353-359 oraz J. Wissego, op. cit., s. 299-361. Szerzej o znaczeniu wypowiedzi Tacyta w tym zakresie zob. zwł. J. Moles, Cry Freedom: Tacitus Annals 4.32-4.35, „Histos” 1998, nr 2, s. 95-184.

35 Zob. F.H. Cramer, op. cit., s. 170; R.A. Bauman, Human Rights..., s. 104.

36 Na temat przesadzonej narracji Swetoniusza (Suetonius, Tiberius, 61.3), w sposób negatywny przedstawiającej cesarza w kontekście crimen maiestatis i tłumienia wolności słowa, zob. D. Rohmann, op. cit., s. 125-126.

37 Zob. ibidem, s. 128.

38 Por. ibidem, s. 132. D. Rohmann utrzymuje, że spalenie mów Scaurusa nie miało związku z przewinieniem wobec Tyberiusza, a ze sprawą zniesławionych senatorów. 
Procesy Scaurusa w odniesieniu do tragedii Atreus oraz ten Cordusa w związ$\mathrm{ku}$ z Annales udowadniają, że rzekome naruszenie maiestas stało się uniwersalnym zarzutem, którym można się było posłużyć w dowolny sposób. Podatność Tyberiusza na argumenty dotyczące ataków na jego osobę była pożywką dla wykorzystywania crimen maiestatis do eliminacji oponentów politycznych, których wypowiedzi, poddane odpowiedniej interpretacji, rozumiane były jako nie tylko prorepublikańskie, a w rzeczywistości stanowiące poważne zagrożenie dla majestatu cesarza ${ }^{39}$.

Analizując palenie ksiąg za rządów Tyberiusza na tle tego zjawiska w czasach Augusta, można by wysnuć wniosek o mniejszym jego znaczeniu po śmierci pierwszego princepsa $\mathrm{w}$ związku z ograniczeniem tej sankcji do jedynie wybranych dzieł danego autora. Konkluzja ta wbrew pozorom nie wydaje się nieuzasadniona. Jakkolwiek bowiem pod panowaniem Tyberiusza doszło do znacznie dalej idących działań mających na celu wyeliminowanie werbalnych i pisemnych głosów krytycznych wobec nowego reżimu i samego cesarza, na tle licznych procesów o crimen maiestati dwa znane przypadki spalenia ksiąg, dodatkowo ograniczone do jedynie niektórych dzieł danego autora, wydają się incydentami o dość nikłym znaczeniu. Obawa przed skazaniem za słowa nieprzychylne władcy na najwyższą karę, przy jednoczesnej niepewności co do dopuszczalnych granic i tak bardzo ograniczonej wolności słowa, odsuwała na dalszy plan kwestię samego palenia ksiąg. Tym samym instrument ten, jakkolwiek wykorzystywany za Tyberiusza, nie musiał stanowić tak odstraszającego środka, za jaki uznać by można podobne incydenty z czasów Augusta. Funkcję tę przejęły bowiem procesy o już wcześniej bardzo pojemne, a teraz wręcz uniwersalne crimen maiestatis $^{40}$.

Ograniczone korzystanie $\mathrm{z}$ instytucji palenia ksiąg w tym okresie pełniło jednak przynajmniej dwie ważne funkcje. $Z$ jednej strony utrwalało bowiem znane już wcześniej zjawisko, podkreślając, że polityka w tym względzie nie tylko nie zmieniła się, lecz została wzmocniona, obejmując nawet dzieła o charakterze historycznym, a co za tym idzie - wskazując, że analizie pod tym kątem poddawane będą nie tylko nowo powstające, ale i wcześniej akceptowane dzieła. Tym samym bezpiecznie w nowym reżimie nie mogli się czuć nawet ci, których krytyczne wypowiedzi nie uzyskały jawnej dezaprobaty Augusta. Dodatkowo podkreślenia wymaga, że oba przypadki palenia ksiąg, jak się wydaje — nieprzypadkowo, dotyczyły — do tej pory niejako chronionych swym statusem — senatorów, jasno

39 T. Polański, op. cit., s. 272, słusznie zauważa, że wspólnym mianownikiem obu tych spraw była retrospektywna lektura i reinterpretacja tekstów, rzekomo wymierzonych przeciw cesarzowi. O realnym lub rzekomym zagrożeniu zamachami w kontekście postawy Tyberiusza zob. np. D. Rohmann, op. cit., s. 128. O zmianie znaczenia maiestas zob. J. Gaudemet, Maiestas populi Romani, [w:] Synteleia V. Arangio-Ruiz, t. 2, red. L. Labruna, A. Guarino, Napoli 1964, s. 701-709; D.J. Kapust, op. cit., s. 19-20. Por. D. Rohmann, op. cit., s. 125-126.

40 Por. I.J. Colunga, op. cit., s. 13-14, który utrzymuje, że Tyberiusz nie nadużywał oskarżeń o maiestas, podkreślając negatywną retorykę Tacyta w zakresie przekazu odnoszącego się do tego władcy. 
dając do zrozumienia, że wysoka pozycja społeczna nie będzie stanowić przeszkody dla wymierzenia „sprawiedliwości” tym, wydźwięk wypowiedzi których nie odpowiada obecnemu reżimowi.

$\mathrm{Z}$ drugiej strony natomiast niekiedy budzący zdziwienie fakt tak ograniczonego zakresu korzystania $\mathrm{z}$ wcześniej już wprowadzonej praktyki palenia ksiąg w kontekście zdeterminowanego dążenia do wyeliminowania wolności słowa za Tyberiusza, przy jednoczesnej rozbudowie interpretacji niedookreślonego naruszenia maiestas, pozwolił na przeniesienie punktu ciężkości polityki ograniczającej krytykę ówczesnej władzy z dzieł spisanych, co do odpowiedzialności z tytułu których i tak nie można było mieć wątpliwości, na wypowiedzi ustne. W ramach szeroko zakrojonych działań mających na celu stłumienie opozycji politycznej zarzuty dotyczące rzeczywiście lub rzekomo wypowiedzianych słów stanowiły bowiem znacznie bardziej elastyczny i pewniejszy sposób na pozbycie się przeciwników. Nie można także wykluczyć, że miało to związek z przeniesieniem niezależnej debaty politycznej z utworów pisanych, podlegających nawet weryfikacji wstecznej, na - zdawać by się mogło, mniej „uchwytne” i, przynajmniej obiektywnie, trudniejsze dowodowo - ustne.

Podkreślenia przy tym wymaga, że zarówno August, jak i początkowo Tyberiusz wykazywali dużą tolerancję $\mathrm{w}$ stosunku do uwag kierowanych pod adresem nich samych, wybaczając, a przynajmniej nie chcąc karać, śmiałości prorepublikańskich czy nawet obraźliwych wypowiedzi dotykających ich bezpośrednio. Jednocześnie w czasach Augusta oraz pierwszych latach panowania Tyberiusza dostrzec można daleko idącą niechęć do korzystania w takich sytuacjach z oskarżeń o crimen maiestatis. $\mathrm{Z}$ tego względu za dość mało prawdopodobne należałoby przyjąć, że senatus consulta pierwszych lat nowej ery, zarządzające spalenie ksiąg, miały być w rzeczywistości formą wyroków kończących senackie postępowania w sprawach dotyczących crimen maiestatis, których w sprawach o zniesławienia jego samego princeps tak chciał uniknąć. Za znacznie bardziej prawdopodobne należałoby uznać, że uchwały senatu, będące podstawą palenia ksiąg w czasach Augusta, miały charakter rozstrzygnięć $a d h o c^{41}$, a dopiero znacznie późniejszy okres, przypadający głównie na drugą połowę rządów Tyberiusza, przyniósł wykorzystanie wcześniejszych praktyk, choć w ograniczonym zakresie, w ramach wówczas już uniwersalnego zarzutu o naruszenie maiestas. Wydaje się przy tym, że właśnie z uwagi na ten zwrot w polityce Tyberiusza i pod jego wpływem postuluje się uznanie, że już za Augusta palenie ksiąg było dodatkową, nową sankcją w wypadku skazania za crimen maiestatis.

Rozważyć jednak należy, czy sytuacja w rzeczywistości nie wyglądała odwrotnie, to jest - czy to nie na skutek polityki Tyberiusza, koncentrującej się w dużej mierze wokół ataków na niego samego, jego najbliższe otoczenie i nową formę państwa, palenie ksiąg z czasów Augusta jest błędnie interpretowane jako działanie wynikające z regulacji dotyczących crimen maiestatis.

41 Por. D. Rohmann, op. cit., s. 146. 
Niezależnie jednak od rozstrzygnięcia tej kwestii wskazane przypadki palenia ksiąg w czasach panowania dwóch pierwszych cesarzy okresu pryncypatu niewątpliwie stanowiły nieczęste ${ }^{42}$, aczkolwiek ważne kroki w ograniczaniu republikańskiej wolności słowa, dobitnie świadcząc o próbach jej tłumienia w odniesieniu do krytyków nowego porządku, będących jednocześnie zwolennikami ustroju republikańskiego, a także przeciwników osób sprawujących władzę. Czy jednak incydenty palenia ksiąg mogły w rzeczywistości wyeliminować niepożądane treści z debaty na temat kwestii politycznych? Dzieła Titusa Labienusa, Cassiusa Severusa i Cremudiusa Cordusa zostały przez Kaligulę zrehabilitowane i uznane za przywrócone do obrotu ${ }^{43}$, a ich posiadanie oraz czytanie nie stanowiło już naruszenia prawa. Prywatne kolekcje i nieoficjalnie sporządzane kopie spalonych dzieł pozwoliły na ich powrót do obiegu. Podkreślenia bowiem wymaga, że poszukiwanie zakazanych ksiąg i ich palenie nie obejmowało prywatnych bibliotek, w ramach których wyjęte spod prawa teksty zostały zachowane ${ }^{44}$. Co więcej, popularność niektórych $\mathrm{z}$ tych dzieł $\mathrm{w}$ dużej mierze opierała się właśnie na tym, że były zakazane ${ }^{45}$. Natomiast przywrócenie ich legalności było niekiedy początkiem końca ich popularności.

Pozostaje zatem pytanie, czy August i Tyberiusz, a także inni sprawujący autorytarną władzę po nich w rzeczywistości mogli liczyć na to, że spalenie ksiąg nieprzychylnych władzy, mające w znaczący sposób ograniczyć wolność słowa, przyczyni się do stłumienia tendencji opozycyjnych. Wydaje się, że nie tylko odpowiedź na to pytanie nie może być twierdząca, ale i nie do końca taki cel przyświecał podjętym przez nich działaniom. Za prawdopodobne można bowiem uznać, że był to wyłącznie sygnał propagandowy, wskazujący na sankcje, z którymi muszą się liczyć osoby, które zdecydują się na praktykowanie prawdziwie republikańskiej wolności słowa. Tym samym nie wydaje się, by chodziło o nadzieje na rzeczywiste wyeliminowanie głosów krytycznych, lecz o ograniczenie ich oddziaływania i rozprzestrzeniania w oficjalnym życiu publicznym, przy jednoczesnym wykreowaniu atmosfery strachu przed sankcjami za „nieprawomyślne" wypowiedzi ${ }^{46}$. Co w tym kontekście jednak najbardziej znamienne, zarówno w starożytnym Rzymie, jak i później palenie ksiąg wpływało raczej na zwiększenie atrakcyjności takich tekstów, sprzyjając, choć nieoficjalnemu, rozpo-

$42 \mathrm{Na}$ temat kontrowersji związanych $\mathrm{z}$ postrzeganiem palenia ksiąg w czasach wczesnego cesarstwa zob. D. Rohmann, op. cit., s. 124 wraz z przyp. 52.

43 Suetonius, Caligula, 16.1; D. Rohmann, op. cit., s. 129; F.H. Cramer, op. cit., s. 194.

44 Zob. M.I. Finley, Censorship in Classical Antiquity, [w:] idem, Democracy Ancient and Modern, New Brunswick 1985, s. 95-96, 99; D. Rohmann, op. cit., s. 128-129.

45 D. Rohmann, op. cit., s. 130.

${ }^{46}$ Interesujący pogląd w tym względzie wyraził M.I. Finley, op. cit., s. 99, wskazujący, że znaczenie treści rozpowszechnianych przez książki i libelli nie było wcale tak duże dla kształtowania opinii publicznej, nawet w zakresie samych elit, zarówno z uwagi na niewielką liczbę ksiąg, jak i czytelników spoza dość ścisłego grona intelektualistów. 
wszechnieniu zawartych w nich treści oraz przyczyniając się w sposób nieunikniony do utrwalania tendencji antyautorytarnych, których oficjalnym przejawom takie postępowanie miało zapobiec ${ }^{47}$.

\section{Bibliografia}

Balzarini M., Ancora sul Lex Cornelia de iniuriis e sulla repressione di talune modalità di diffamazione, [w:] Estudios en Homenaje al Profesor Juan Iglesias, red. J.R. Esteve, t. 2, Madrid 1988.

Balzarini M., „De iniuria extra ordinem statui”. Contributo allo studio del diritto penale romano dell'età classica, Padova 1983.

Bauman R.A., The Crimen Maiestatis in the Roman Republic and Augustan Principate, Johannesburg 1967.

Bauman R.A., Human Rights in Ancient Rome, London 2000.

Braund S.M., Libertas or licentia? Freedom and Criticism in Roman Satire, [w:] Free Speech in Classical Antiquity, red. I. Sluiter, R.M. Rosen, Leiden-Boston 2004.

Bryen A.Z., Labeo's iniuria: Violence and Politics in the Age of Augustus, „Chiron” 2018, nr 48.

Chinn Ch., "Libertas Reverentiam Remisit": Politics and Metaphor in Statius "Silvae” 1.6, „The American Journal of Philology" 129, 2008, nr 1.

Chrissanthos S.G., Freedom of Speech and the Roman Republican Army, [w:] Free Speech in Classical Antiquity, red. I. Sluiter, R.M. Rosen, Leiden-Boston 2004.

Colunga I.J., Untangling a Historian's Misinterpretation of Ancient Rome's Treason Laws, „Journal Jurisprudence" 2011, nr 9.

Corbeill A., Ciceronian Invective, [w:] Brill's Companion to Cicero: Oratory and Rhetoric, red. J.M. May, Leiden 2002.

Coudry M., Sénatus-consultes et acta senatus: rédaction, conservation et archivage des documents émanant du sénat, de l'époque de César à celle des Sévères, [w:] La mémoire perdue. À la recherche des archives oubliées, publiques et privées, de la Rome antique, red. S. Demougin, Paris 1994.

Cramer F.H., Bookburning and Censorship in Ancient Rome: A Chapter from the History of Freedom of Speech, „Journal of the History of Ideas” 6, 1945, nr 2.

D'Hautcourt A., L'exile de Cassius Severus: hypothèse nouvelle, „Latomus” 54, 1995, nr 2.

Díaz de Valdéz J.M., Freedom of Speech in Rome [Libertad de expresión en Roma], „Revista de Estudios Histórico-Jurídicos" 2009, nr 31.

Finley M.I., Censorship in Classical Antiquity, [w:] idem, Democracy Ancient and Modern, New Brunswick 1985.

Forbes C.A., Books for the Burning, „Transactions and Proceedings of the American Philological Association" 1936, nr 67.

Gaudemet J., Maiestas populi Romani, [w:] Synteleia V. Arangio-Ruiz, t. 2, red. L. Labruna, A. Guarino, Napoli 1964.

Henning D., T. Labienus und der erst Majestätprozeß de famosis libellis, „Chiron” 1973, nr 3.

Herrin J., Book Burning as Purification, [w:] Transformations of Late Antiquity. Essays for Peter Brown, red. P. Rousseau, M. Papoutsakis, Farnham 2009.

$47 \mathrm{Na}$ temat późniejszych aktów palenia ksiąg w starożytnym Rzymie sumarycznie zob. C.A. Forbes, op. cit., s. 124-125; T. Polański, op. cit., s. 273-277; J.A. Howley, op. cit., s. 218 oraz 226-231; D. Rohmann, op. cit., s. 137-143. 
Howley J.A., Book-Burning and the Uses of Writing in Ancient Rome: Destructive Practice between Literature and Document, „The Journal of Roman Studies” 2017, nr 107.

Kapust D.J., The Case of Cremutius Cordus: Tacitus on Censorship and Writing under Despotic Rulers, [w:] Censorship Moments: Reading Texts in the History of Censorship and Freedom of Expression, red. G. Kemp, London-New Delhi-New York-Sydney 2015.

Manfredini A.D., La diffamazione verbale nel diritto romano, Milano 1978.

Mattingly H.B., Naevius and the Metelli, „Historia: Zeitschrift für Alte Geschichte” 9, 1960, nr 4.

McHugh M.R., Historiography and Freedom of Speech: The Case of Cremudius Cordus, [w:] Free Speech in Classical Antiquity, red. I. Sluiter, R.M. Rosen, Leiden-Boston 2004.

Moles J., Cry Freedom: Tacitus Annals 4.32-4.35, „Histos” 1998, nr 2.

Mucciacia G., In tema di repressione delle opere infamanti, [w:] Studi in onore di Arnaldo Biscardi, t. 5, Milano 1984.

Nowicka D., Rzymski senat a wolność stowa, [w:] Zgromadzenia stanowe i organy przedstawicielskie w dziejach. Księga jubileuszowa dedykowana Profesorowi Marianowi Józefowi Ptakowi, red. J. Koredczuk, P. Wiązek, Wrocław 2020.

Nowicka D., Some Remarks on Criminalization of Written Defamation in Roman Classical Law, [w:] "They Called Me to Destroy the Wicked and the Evil": Selected Essays on Crime and Punishment in Antiquity, red. S. Nowicki, Münster 2016.

Nowicka D., Zniesławienie w prawie rzymskim, Wrocław 2013.

Polański T., The Destructive Force of Roman Censorship. A Retrospective View across the Limes, [w:] Essays in Honour of S. Stabryła, red. S. Styka, Kraków 2007.

Raaflaub K.A., Aristocracy and Freedom of Speech in the Greco-Roman World, [w:] Free Speech in Classical Antiquity, red. I. Sluiter, R.M. Rosen, Leiden-Boston 2004.

Robinson L., Freedom of Speech in the Roman Republic, Baltimore 1940.

Rogers R.S., The Case of Cremutius Cordus, „Transactions and Proceedings of the American Philological Association" 1965, nr 96.

Rohmann D., Book Burning as Conflict Management in the Roman Empire (213 BCE-200 CE), „Ancient Society” 2013, nr 43.

Rudich V., Navigating the Uncertain: Literature and Censorship in the Early Roman Empire, „Arion” 2006, nr 14.

Santalucia B., La carcerazione di Naevio, [w:] idem, Altri studi di diritto penale romano, Milano 2009.

Sarefield D.C., Bookburning in the Christian Roman Empire. Transforming a Pagan Rite of Purification, [w:] Violence in Late Antiquity, red. H.A. Drake, Aldershot 2006.

Seager R., Maiestas in the Late Republic: Some Observations, [w:] Critical Studies in Ancient Law, Comparative Law and Legal History, red. J.W. Cairns, O.F. Robinson, Oxford 2001.

Smith R.E., The Law of Libel at Rome, „The Classical Quarterly” 1, $1951 \mathrm{nr}$ 3-4.

Starr Jr. Ch.G., The Perfect Democracy of the Roman Empire, „The American Historical Review” $58,1952, \mathrm{nr} 1$.

Steel C., Name and Shame? Invective against Clodius and Others in the Post-Exile Speeches, [w:] Cicero on the Attack: Invective and Subversion in the Orations and Beyond, red. J. Booth, Swansea 2007.

Tränkle H., Zu Cremutius Cordus fr. 4 Peter, „Museum Helveticum” 37, 1980, nr 4.

Vannucci A., I giornali presso gli antichi Romani, „Archivio Storico Italiano. Nuova Serie” 9, 1859, nr 1.

Watts E., Introduction: Freedom of Speech and Self-Censorship in the Roman Empire, „Revue Belge de Philologie et d'Histoire / Belgisch Tijdschrift voor Filologie en Geschiedenis” 2014, nr 92.

Wirszubski Ch., Libertas as a Political Idea at Rome during the Late Republic and Early Principate, Cambridge 1950.

Wisse J., Remembering Cremutius Cordus: Tacitus on History, Tyranny and Memory, „Histos” 2013, nr 7.

Studia nad Autorytaryzmem i Totalitaryzmem 43, nr 4, 2021

(C) for this edition by CNS 